\title{
Improving Academic Skills on Freshmen Student Performance in Mastering Learning Skills
}

\author{
Deny A. Iyai ${ }^{*}$, Siska Syaranamual ${ }^{2}$, Alexander Yaku $^{3}$ \\ ${ }^{1}$ Department of Animal Science, University of Papua, Manokwari, Indonesia \\ 2,3 Department of Agriculture, University of Papua, Manokwari, Indonesia \\ e-mail: da.iyai@yahoo.com ${ }^{1}$, siskasyaranamual@hotmail.com², axyaku@yahoo.com³
}

\begin{abstract}
This study aims to describe the capacity of students' learning skills, provide and develop problem-solving learning skills, prepare appropriate modules that are used by students, and encourage counseling and learning development units. The method used in this action research is a qualitative research design. The research technique was carried out by using a case study approach and observation. The results showed that the students' mathematical abilities ranged from 26-50 (57.14\%). Only 14\% (11.43\% + $2.86 \%$ ) of AgtSP students have capacities in basic mathematics. Learning skills, for example, reading and writing, had lower AgtSP values, namely 37.14\% and 34.29\%. AgtSP is still dominated by Papuan students (86\%) and a small proportion of non-Papuan students (14\%). Many students enrolled in AgtSP graduated from Social Sciences (38\%), some graduated from Agricultural High School (33\%), and a few graduated from natural sciences $21 \%$ ) and a small number of students graduated from Non. Agricultural Senior High School, namely administration interest. Student GPA has increased in the number of students who have GPA scores. 23 components affect student learning skills at the university level as experienced by AgtSP. The conclusion is the low scores obtained by mathematics, reading, and writing students enrolled in the Faculty.
\end{abstract}

Keywords: Freshmen Students, Learning Skills, Performance

\section{Introduction}

Papua University (UNIPA) is the only one state university locating in Manokwari, West Papua province. The university was established in the year of 2000 that was developed from Faculty of Agriculture, Cenderawasih University. At the time of establishment, the university consisted of six faculties and 31 study programs. Total number of UNIPA students body today are more or less 7000 students, enrolling in different study programs and they are generally come from different high schools across Papua and West Papua provinces, which have limited learning skills (Aliyyah et al., 2019; Purnastuti \& Izzaty, 2016) and knowledge due to school performances (Booth et al., 2019). The representation of students from different high school background is possible since UNIPA apply the local student recruitment system called SESAMA which is admission of high school graduation to university based on the high school academic performance. In addition to SESAMA, admission of new students to UNIPA can also go through national admission which are SNMPTN and SBNPTN and the university admission (Prasetyaningsih, 2015; Rifa'i B, 2018; Takriyuddin et al., 2016). The university test is carried out for certain study programs when their number of students are not fill the quote and apply for students who will enroll in diploma or vocational programs. The admission of the students through SESAMA was launched because prior to 2000, admission selection to enter Papua State University was conducted nationally through College Admission Selection called SMPTN (Brewis, 2018; Haryanti et al., 2016)

Using the national selection, many Papuan students coming from remote areas and low-income families cannot enroll some the state universities in Papua. The local students' recruitment system in practice has advantages and disadvantages. The advantages of the system are that: the high school graduation from different areas of Papua can be selected, many Papuan have a chance to enroll in Papua University and the university can play its rule

\footnotetext{
${ }^{*}$ Corresponding author.

Received 26 April 2020; Accepted 16 September 2020; Available online 25 March 2021 (C) 2020 JPI. All Rights Reserved
} 
in educate people in Papua; however the system has disadvantages which not all high schools in Papua have the same standard of quality so that it affect the student academic performance, it seems there is a manipulation of high school grade by school administrator in several high school to make their student can be accepted in university and it is found that students enter university through local selection do not perform well as indicated by their high school grade. Data of students of Faculty of Agriculture and Agricultural Technology (FAAT) and Agrotechnology Study Program (AgtSP) has shown significant increasing since 2008.

The AgtSP student body in 2012/2013 is 1085 . Trend number of students seems to be declined. Performance of GPA of AgtSP in some years tends to decline. Lower, middle and higher GPA in 2012/2013 of AgtSP were 2.10, 2.99 and 3.77. The proportion seems to increase 30.0, 35.0 and 35.0. The academic performances as Unipa's student are determined by study environment during the senior high schools. Many high schools in Papua do not offer a good environment for student to learn because schools do not have good facilities such as good class rooms, library, laboratory and also do not have a qualified teacher of each subject being tough. This situation is often not only occurred in remote areas but it occurs also in several high schools around the cities both in Papua and Papua Barat provinces. Performance of students in university is determined by its background during studying in the previous schools and outside learning activities.

Background of students here means those things which are available, prepared and used by students. Facilities, teachers, and teaching activities determine students' capacities. While entering university, students will face new environment. Not only campus atmosphere is, but living circumstances are also determining student capacity and performances. Campus atmosphere means those with related to academic including and limited to sciences and technological activities determining student attitude and performances (Astuti et al., 2016; Yusuf, 2018). Activities with related to it are teaching, tutor/bridging program, self-study, academic facilities, lecturer coaching/advisory.

University learning systems are academic and non-academic activities with related to learning and study skills and other knowledge and technologies needed by student to achieve good performance (Astuti et al., 2016; Brewis, 2018; Burhanuddin et al., 2016; Hendrayana et al., 2014; Purnastuti \& Izzaty, 2016; Wibowo \& Lestari, 2019). Good performance of the students can be seen from its GPA and other academic activities such as writing skills, presenting skill, communication skill, etc. (Aliyyah et al., 2019; Astuti et al., 2016; Hendrayana et al., 2014; Saifudin, 2017; Wasahua, 2018; Wibowo \& Lestari, 2019; Yusuf, 2018). A program being considered can help students to adjust to university learning system is by introducing students with learning skill capacities. Papua University has no such models of learning skills so far. Therefore, this pilot project of Action research project was introduced by Higher Education and Leadership Management-USAID thorough AgtSP in FAAT. Such learning skills should therefore be identified from students' capacities. The assumption is that by knowing components of learning skill being toughed, student will enjoy in studying and in turn their academic performance in term of GPA will increase.

Therefore, the objectives of this action research were to implement capacity of learning skills of the freshmen students of the Agro technology Study Program, and to provide and develop problem-solved learning skills.

\section{Method}

Participants were selected from 2014 enrolled students in AgtSP. They involved as well in session of Focus Group Discussion, Placement test (trial), and pilot questionnaires (Moleong, 1991; Yin, 2000). An FGD was also done in Faculty of Animal Husbandry by obtaining lecturer perception of learning skills of students and constraints faced by students and academic environment in UNIPA. A number of 15 lecturers was involved. Procedures in conducting research action were done by following diagram shown in the left side of body text (Figure 1). In placement test, which attached with university program namely PKKMB, three basic learning skills were tested, i.e. Math, Reading and Writing (Figure 2). 


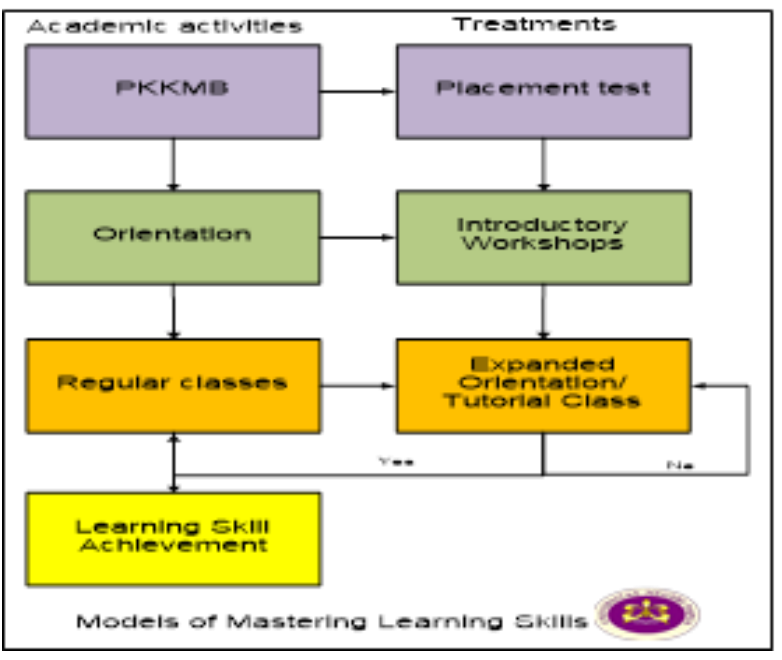

Figure 1. Models of mastering learning skills

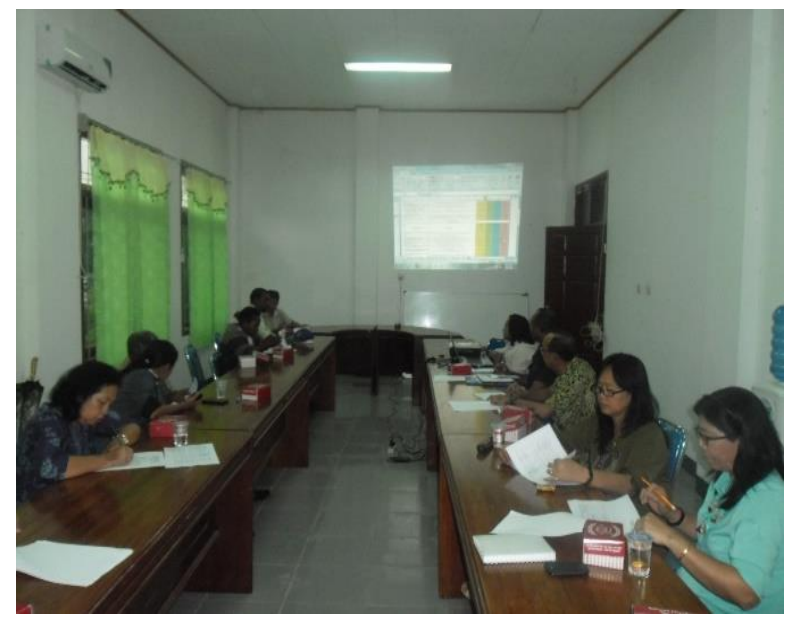

Figure 3. Socialization into expanded team and facilitators

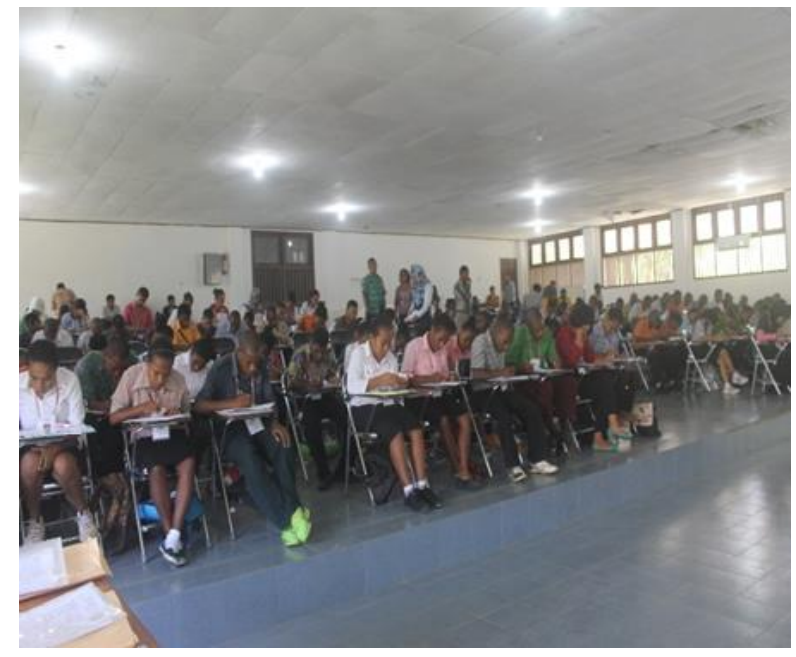

Figure 2. Placement test taken during Faculty Orientation

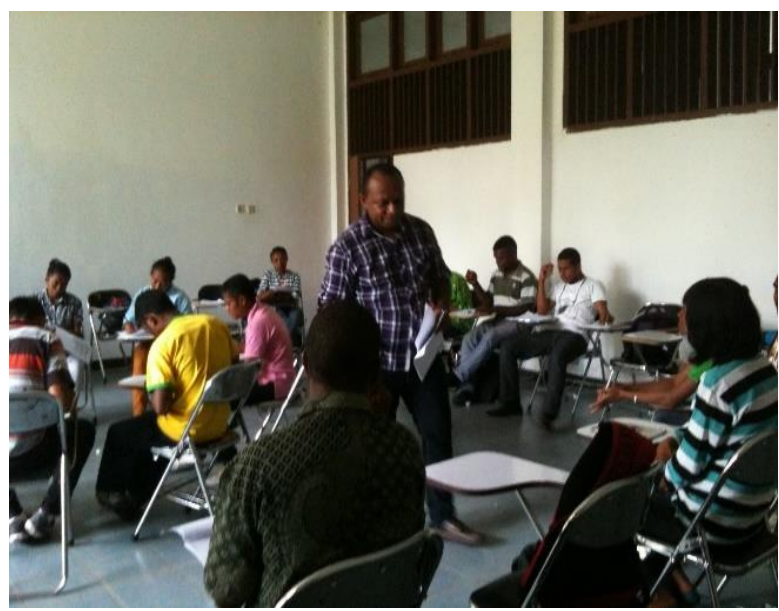

Figure 4. Weekly activity-Reading Class

Data of placement test then combined as well as questionnaires for deriving actions needed during implementing the mastering learning skills in classes. After placement test, expanded team teaching was made and arranged (Figure 3.) to construct the modules including methods and all technical aspects such as monitoring and evaluation. Following placement test, introductory workshop was done inside the class. In this session, several skills of learning were introduced, namely motivation, reading, writing, computers including internet browsing, and time management (Figure 4.). Soon after, a regular class for 9 learning skills was formally scheduled. Time schedule for Math was done every week on Friday. Reading, writing, and other six skills were scheduled on Saturday morning. Classes were prepared by list of attendances, LCD, responsible persons who were controlling and monitoring the classes. Materials of weekly activities were made during two weeks before university introductory (PKKMB) session. Outline of the module was designed and being thought to the students. Not only a test was done in placement test, in measuring student performance during regular classes on weekly activity, a pre- and post-test was done for three basic skills, i.e. math, reading and writing. Instruments of the action research in AgtSP were Performances of $1^{\text {st }}$ year students (2003) of Faculty of Agriculture and Agricultural Technology. GPA is student achievement of academic in each semester. It is measured by grades and categorical (Excellent= GPA >3.5, Good=GPA 3.0-3.49, Fair=GPA 2.50-2.99, Sufficient=GPA 2.00-2.49, 
and Fail=GPA <1.99). Self-assessment of learning skills was made based on performances of basic skill of learning in terms of math, reading, writing, speech (presentation skill), Computer (Word and Data Operation, Internet Browsing), and Library skills. Scores of learning skills were determined based on these four components. Perception of learning skills was done to know how student perceive their learning skills.

Opinion of Academic student services was measured on response of student as consumers towards academic services (Wahyuningsih, 2016). Identification of learning skills was surveyed using questionnaire (Moleong, 1991; Yin, 2000). Learning commitment was done to know how students of AgtSP committed to have serious learning. Grades of post-test, i.e. results obtained during attending period of orientation program in line with math (Prasetyaningsih, 2015; Sampurno \& Efendi, 2014), reading (Aliyyah et al., 2019; Wibowo \& Lestari, 2019), and writing (Wahyuningsih, 2016). Increasing knowledge was measured using following formulae based on Ginting (1991).

Analyses of the data were done based on descriptive and inferential statistic (Asra \& Sutomo, 2016; Santoso, 2012). Besides, quantitative and qualitative methods were analyzed using non parametric statistical test (Santoso, 2012). All the data were presented in descriptive statistic. Statistical inference, i.e. T-test (Ott \& Longnecker, 2001), was done to compare the GPA of students without and having this treatment, i.e. 2013 and 2014, respectively

\section{Result and Discussion Marks of Placement test}

Table 1. described that Mathematic skill of students in average was in grade ranges of 26-50 (57.14\%), which is still below expectation of under graduate University. Only $14 \%$ $(11.43 \%+2.86 \%)$ students of AgtSP have capacity of basic Math. Under this faculty, in the field of Math, AgtSP has better marks compared to other study programs.

Table 1. Placement test score learning skills of the five study programs in Agriculture Faculty.

\begin{tabular}{ccccccc}
\hline \multirow{2}{*}{$\begin{array}{c}\text { Learning } \\
\text { Skill }\end{array}$} & \multirow{2}{*}{ Range } & \multicolumn{5}{c}{ Proportion (\%) } \\
\cline { 3 - 7 } Math & $0-25$ & AgtSP & Agribisnis & THP & D3 PKB & D3 Pangan \\
\hline \multirow{5}{*}{ Reading } & 26.57 & 18.92 & 33.33 & 50 & 100 \\
& $51-75$ & 57.14 & 67.57 & 64.29 & 50 & 0 \\
& $76-100$ & 11.43 & 10.81 & 0 & 0 & 0 \\
& $0-25$ & 2.86 & 2.7 & 2.38 & 0 & 0 \\
& $26-50$ & 25.71 & 0.00 & 16.67 & 12.5 & 0 \\
Writing & $51-75$ & 37.14 & 37.84 & 35.71 & 43.75 & 60 \\
& $76-100$ & 34.29 & 35.14 & 38.10 & 6.25 & 40 \\
& $0-25$ & 28.57 & 5.41 & 19.05 & 37.5 & 0 \\
& $26-50$ & 20.00 & 37.84 & 35.71 & 31.25 & 20 \\
& $51-75$ & 37.14 & 40.54 & 45.24 & 25 & 80 \\
& $76-100$ & 14.29 & 16.22 & 0.00 & 6.25 & 0 \\
\hline
\end{tabular}

AgtSP=Agroteknologi Study program, THP=Teknologi Hasil Pertanian (THP), D3 PKB= Diploma III Perkebunan

In line with other learning skills, for instance reading and writing, AgtSP has lower marks by percentages, i.e. $37.14 \%$ and $34.29 \%$ (71\%) compared to Agribisnis (Bachelor), THP (Bachelor), Tanaman Pangan (Diploma) and Perkebunan (Diploma) study program. Therefore, by following learning skills class, lag in skills of Math, reading and writing of students will be improved. The marks of math in lower ranges as well will be lowered and knowledge and skills for math and the other two will then improve. This will useful in attending several basic courses such as Math, Chemistry, Physic and agricultural-related courses (Burhanuddin et al., 2016). 


\section{Students' ethnicities}

We were also interested in understanding ethnicity of the students (Brewis, 2018). Students based on ethnicities dominated by Ayamaru-Papua (21\%) followed by Arfak and Byak -Papua (13\%) and Dani-Papua (9\%), Toraja (8\%). While Yally-Papua, Onate-Papua, Kais-Papua (Sorong), Betwe-Papua, Bonggo (Jayapura) -Papua, Mandobo (Merauke) Papua, Lanny-Papua, Java, and Kimyal-Papua had similar percentages (4\%). The AgtSP still has dominated by Papuan students (86\%) and the small number of non-Papuan student (14\%), i.e. Java and Toraja. This figure described that classes were dominated by Papuan. It was hoped that the Papuan would also made interaction with the non-Papuan students. The interaction is important when students will share and exchange their knowledge and sciences each other (Astuti et al., 2016; Burhanuddin et al., 2016).

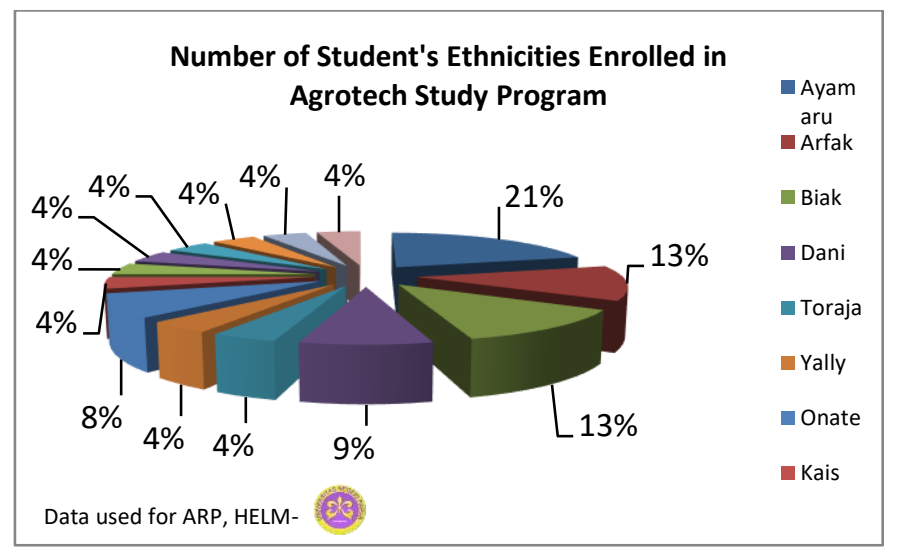

Figure 5. Ethnicity of the students enrolled in AgtSP, Papua University

\section{Origin of Senior high school}

Data from Figure 7. shown that high number of students enrolled in AgtSP were graduated from Senior High of Social Science (38\%), some were graduated from Agricultural related Senior High School (33\%), and few were graduated from natural sciences $21 \%$ ) and small number of students were graduated from Non-Agricultural Senior high schools, i.e. administration interest. Diversity of students resources were vast (Aliyyah et al., 2019; Astuti et al., 2016).

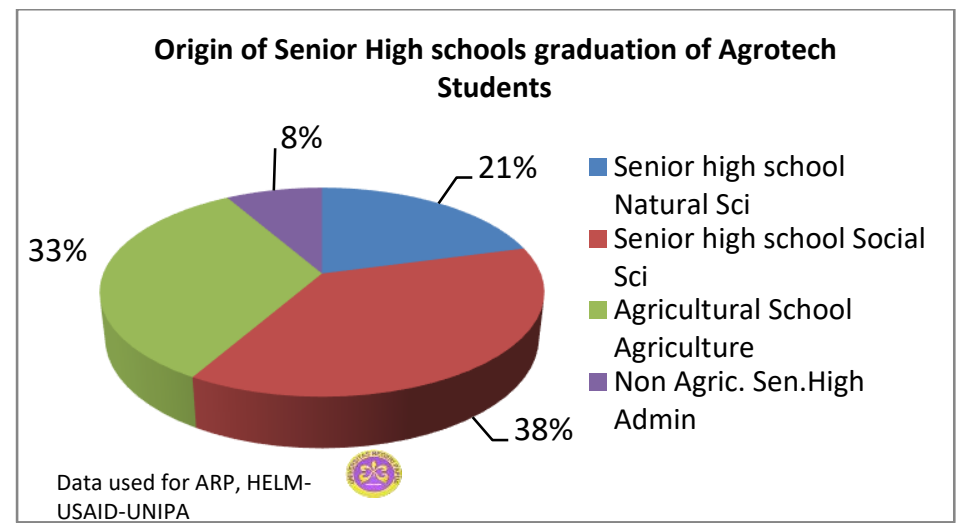

Figure 6. High school profiles of enrolled AgtSP Student of year 2014.

It seems that the enrolled students having suitable linear knowledge with AgtSP was senior high school in Natural Sci. (21\%), Agricultural related-high school (33\%). Therefore, in general the total number of suitable students was $54 \%$. Other, i.e. $46 \%$ were not suitable enrolled in AgtSP. It is therefore, number of suitable nominating students enrolled in AgtSP should be increased by socialization and selection stages (Aliyyah et al., 2019; Joanne V. 
Wood, 1989; Usman \& Daud, 2015). By doing that, the targeted schools will better prepare their students to fulfill the university requirement. University requirement is having good in knowledge, science, skills, social skills, life skills and emotional skills (Usman \& Daud, 2015; Wibowo \& Lestari, 2019).

\section{Analyses of mastering learning skills}

Figure 5. shown that Math skill has minor increase marks between pre-test and posttest. Similar number as well depicted in reading skills and writing skills. In reading skills, minor improvement occurred in marks of 51-75 and 76-100. Writing performance was shown that changes were occurred in 51 to 75 and 76-100. Generally, students have performance on range of $26-50$ and $51-75$ for all three learning skills (Figure 6). Writing and reading have improved very much.

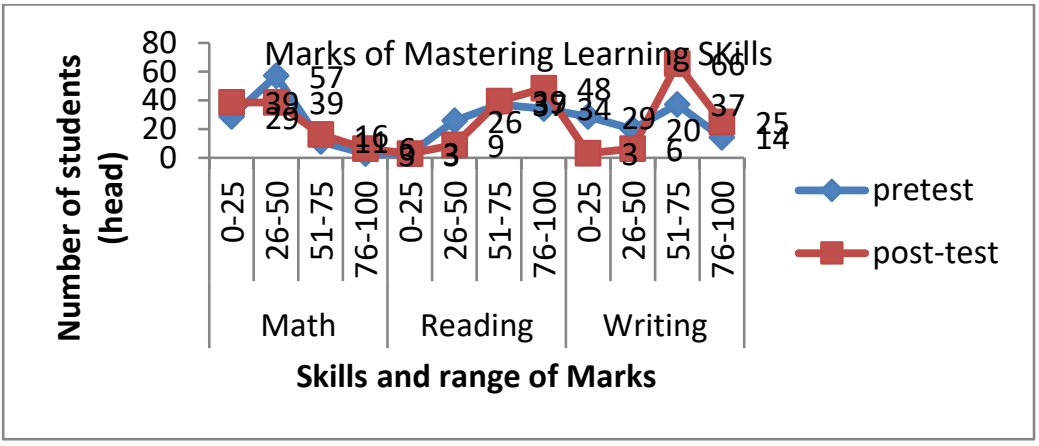

Figure 7. Marks of learning achievement on 2014 students of Agrotech study program.

From the three skills above, it can be seen that learning capacity of the students occurred and changed in this group of students (Figure 8). However, the changes from small marks of learning skills to higher marks will take long period of time and hard work effort from both parties, i.e. students and lecturers (Burhanuddin et al., 2016; Purnastuti \& Izzaty, 2016; Wahyuningsih, 2016; Yusuf, 2018). Example can be seen from evaluation of reading test concerning knowledge of the materials (Figure 9). A test to examine the knowledge of the material was done by offering students with pre-test and post-test. The result of this finding shown that $32 \%$ and $36 \%$ Students had improved their reading skills.

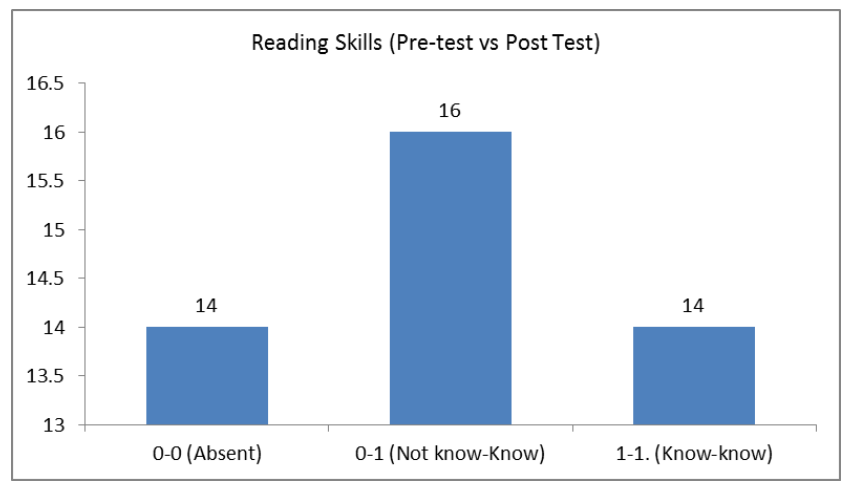

Figure 8. Evaluation of knowledge exchange in Reading skills

\section{Grade Point Average (GPA) of The Students}

In general, Figure 1 shown that the learning process seen from the $1^{\text {st }}$ semester up to $2^{\text {nd }}$ semester had slightly down. The trend of declining GPA of students could be explained from how best students adapted quickly from old or previous circumstance to existing and/or present situation at new and a bit strange academic environmental (Burhanuddin et al., 2016; Wahyuningsih, 2016; Wasahua, 2018). 


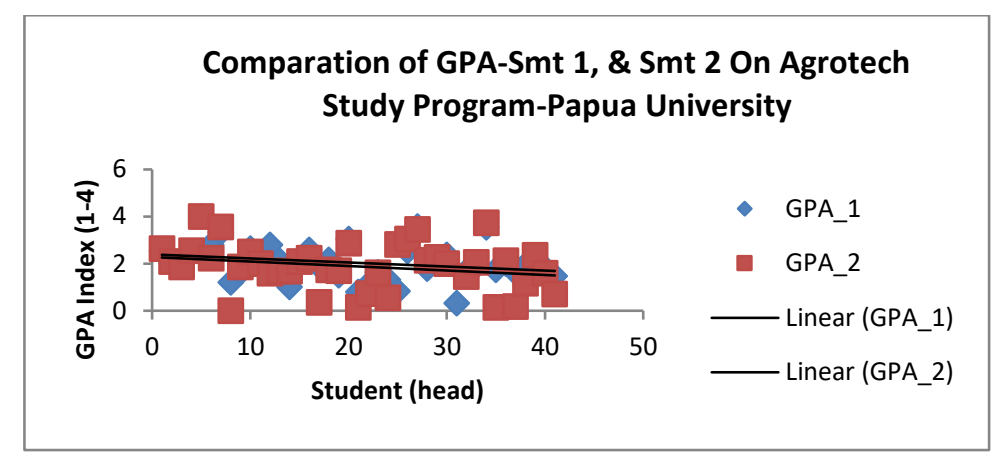

Figure 9. Comparison of GPA $1^{\text {st }}$ semester and $2^{\text {nd }}$ semester

The GPA of student had been increased in number of students having marks in GPA. The 2013-year students had low performances of GPA compared to 2014 students. Students with low GPA (<2) had lowered from 25 head to 18 head, shown positive changes. Students having GPA of 2.00-2.50 had decreased. Students with GPA of 2.50-3.00 and 3.00-3.50 had similar number in both years.

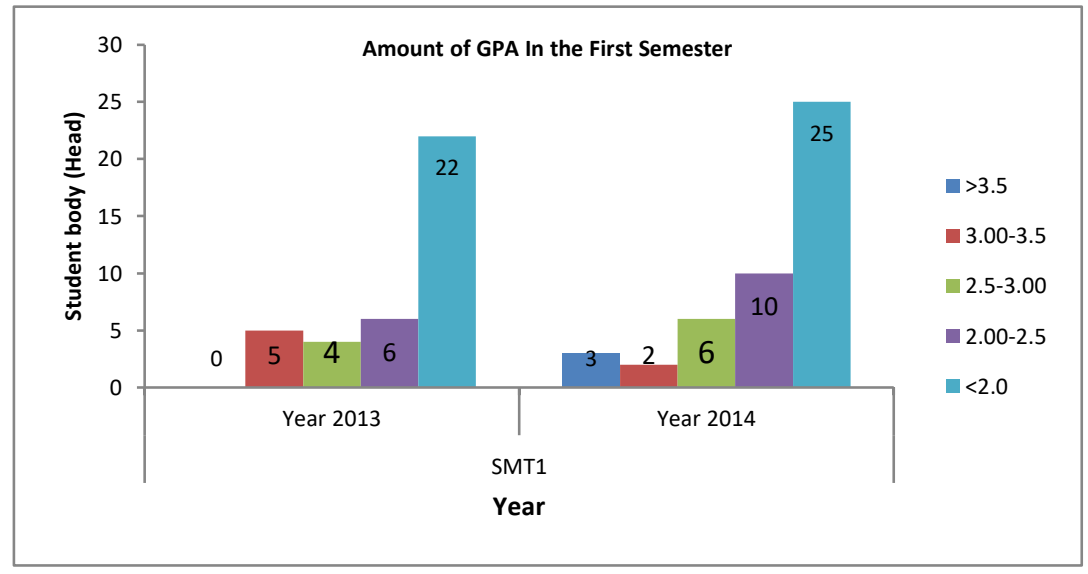

Figure 10. GPA achievement in $1^{\text {st }}$ Semester

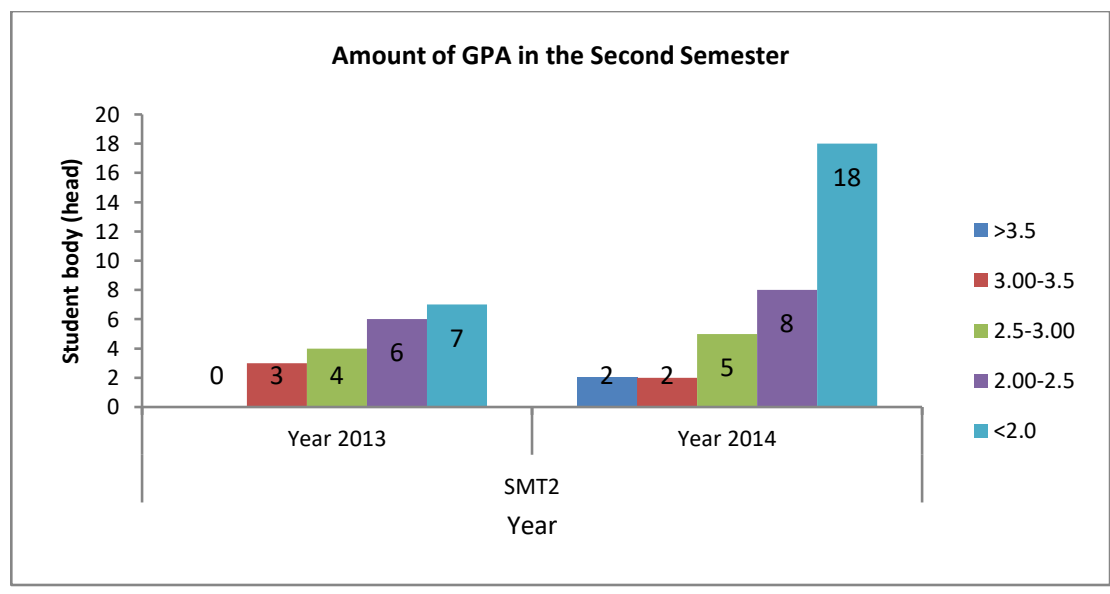

Figure 11. GPA achievement in $2^{\text {nd }}$ Semester

Using T-test, GPA of the first and second semester of 2013 and 2014 students was analyzed. It was found that there was no difference $(p>0.05)$ between the two groups. The average GPA of the enrolled first students of 2013 was $1.95 \pm 0.87$ and $2.07 \pm 0.72$ and the second was $2.07 \pm 0.72$. While in the year 2014 , the average GPA of $1^{\text {st }}$ semester was 
$1.95 \pm 0.87$ and $1.97 \pm 0.98$. In total, GPA of $2^{\text {nd }}$ semester has small increased number, i.e. $1.98 \pm 0.81$.

\section{Discussions}

Student performances are affected by social, psychological, economic, environmental and personal factors. One of Indicators of student performances is GPA (Galiher, 2006). We inventory five categories that limit and challenge student performance, i.e.: Personal, Social, Academic, Life issues and Institutional Issues. Similar finding reported by Fishman et al. (2003). In personal issue, item such as lost, stress, undisciplined, unmotivated and insecure are included. In academic component, factors are underprepared, poor study habits, low academic performance. Life issues include insecurity concerning financial, home and family difficulties, personal problems, health problems and college not necessary to meet career goals. Institutional issue includes experience operational problems, experience negative attitudes in the classroom, advising centers and administrative offices.

Other factors affecting student performances are based on character of individual and feedback. Individual differences comprise of gender, age, existing level of skill, motivation for learning, and fitness levels. Gender consists of differences in physique, interests and motivation. Boys are likely to be motivated by a desire to compete whereas girls are more likely to participate for associative reasons. Age refers to an individual's state of readiness. Existing level skills refer to some learners have already developed different levels of co-ordination, balance, speed and other skill-related fitness components that may contribute to faster learning. Motivation for learning means that a learner who is interested in developing skill and playing the game will have an advantage over others who are not motivated to the same extent. Fitness level describes a higher level of fitness has been shown to improve concentration and physical performance. It also allows learners to work for longer before fatiguing which is a key factor when learning skills. Previous experiences give a learner with previous exposure to the skill being learnt will have both a cognitive and physical advantage. Feedback provides the learner with vital information that compares the current performance with the desired one (Brady, 2005; Darling-hammond \& Snyder, 2000; Fishman et al., 2003; Lassig, 2020; Maas et al., 2017; Reddy et al., 2019; Zhou et al., 2020). Feedback comes in many different forms, i.e. internal and external. Internal means how something feels e.g. in gymnastics you can feel that the cartwheel was straight. External means information received via the senses e.g. visual and aural.

The finding of the $23^{\text {rd }}$ components affecting student learning skills in university level was experienced by AgtSP students. From these components we have categorized it into seven major components, i.e. low motivation, poor time management, low adjustment to university teaching method, access to campus, lack of self-directed learning, bad medical condition and overload assignment. These components then could be grouped into inside and outside factors. Inside factors constituted low motivation (Wasahua, 2018; Wibowo \& Lestari, 2019), poor time management (Aliyyah et al., 2019; Wasahua, 2018), lack of self-directed learning (SDL), and bad medical condition. Outside factors were low adjustment to university teaching methods and overload assignments. Motivation has strategic point inside an individual which drive someone to move on in every activity (Brady, 2005; Farrington \& Small, 2008; Fishman et al., 2003; Vignery \& Laurier, 2020). Without motivation someone will not do something optimal and someone will not achieve better results. Someone will not work effectively and efficiently. Someone will not use his time in wise manner. His/her time management achievement will be lower than someone having high motivation. Someone will use his/her time management ineffectively. Someone will have low adjustment to university teaching method due to his/her motivation and time allocation (Meyers, 2003; Miller, 2003; Shaw et al., 2002). As a result, he/she will not have chances to adjust on university teaching methods. In one hand, he/she will have problem entering access to campus. Frequency access to campus has been a cause why students have low marks.

Class presences are always counted as requirement to attending the mid and final test. Due to low motivation, students will also have lack of SDL (independent learners) to develop learning skills. Student will not have time to develop their capacity in reading, writing and math 
(Grauerholz, 2001; Keig, 2001; Stamatoplos, 2000). One factor identified was bad medical condition (Fishman et al., 2003; Keinänen et al., 2018; Meens et al., 2018). This will affect students on low participation in presence and class activities. Overload assignments become the problem due to low in financial support and management, high expectation of parents, inadequate prior knowledge for supporting speaking skills, too much dictation (one-way learning), low access into university library, and low participation on training or courses (Darling-hammond \& Snyder, 2000; Kilgus et al., 2018; Lassig, 2020; Maggin et al., 2012).

\section{Conclusions and Suggestions}

The Math, reading and writing of students enrolled in Agriculture Faculty performed low marks. This number appeared due to high school field background dominated by social science. The schema implemented was succeeded in increasing learning skills by comparing pre-test and post-test during program was run. In the end, the program achieved slight increasing number of GPA marks of the students involved in this program on the $1^{\text {st }}$ and $2^{\text {nd }}$ semesters. The implication of this action research under theme of learning skills is applicable under situation of Papua University. Other faculties even other universities having similar condition could apply this schema and indeed by making some adaptation in order to meet the need and performances of the representative students enrolled. Economically the program is low cash and no need to apply for high budget. All students will feel freedom in studying and lecturers will no need to spend many hours in improving learning skills during following higher rank of semester, particularly in writing and presenting the assignment and final research and seminars.

\section{References}

Aliyyah, R. R., Rosyidi, U., \& Yazid, R. (2019). An Evaluative Study of an Education Scholarship Program ( BidikMisi ) for Students in Indonesia An Evaluative Study of an Education Scholarship Program ( BidikMisi ) for Students in Indonesia. Journal of Physics; Conf. Series, 1175, 7. https://doi.org/10.1088/1742-6596/1175/1/012171.

Asra, A., \& Sutomo, S. (2016). Pengantar Statistika I (1st ed.). PT. Rajagrafindo Persada.

Astuti, F. B., Sumarwan, U., \& Qayim, I. (2016). The Role of Student Engagement in the Success of Study of Scholarship Awardee Students of Bogor Agricultural University, Indonesia. $3(3)$,

106-114. https://doi.org/10.20448/journal.509/2016.3.3/509.3.106.114.

Booth, A., Purnagunawan, R. M., \& Satriawan, E. (2019). Towards a Healthy Indonesia? Survey of Recent Developments. 4918. https://doi.org/10.1080/00074918.2019.1639509.

Brady, A. (2005). Assessment of learning with multiple-choice questions. 238-242. https://doi.org/10.1016/j.nepr.2004.12.005.

Brewis, E. (2018). Fair access to higher education and discourses of development: a policy analysis from Indonesia. Compare: A Journal of Comparative and International Education, 7925, 1-18. https://doi.org/10.1080/03057925.2018.1425132.

Burhanuddin, T., Ruswan, A., \& Kasmad, M. (2016). Differences of Learning Achievement between Bidikmisi Scholarship Students and the Paying Students in Islamic Courses at Indonesia University of Education Campus Purwakarta Academic Year 2014-2015. Journal of Education and Practice, 7(32), 52-56.

Darling-hammond, L., \& Snyder, J. (2000). Authentic assessment of teaching in context. 16, 523-545.

Farrington, C. A., \& Small, M. H. (2008). A New Model of Student Assessment for the 21st Century.

Fishman, B. J., Marx, R. W., Best, S., \& Tal, R. T. (2003). Linking teacher and student learning to improve professional development in systemic reform. 19, 643-658. https://doi.org/10.1016/S0742-051X(03)00059-3. 
Fuadi, F., Nirzalin, N., Apridar, A., Umaruddin, U., \& Muhammad, D. (2015). Science and Technology Program for Entrepreneurship (STPE) of Malikussaleh University in North Aceh. Educational Research International, 4(5).

Ginting, E. (1991). Metode Kuliah Kerja Lapangan. Universitas Brawijaya.

Grauerholz, L. (2001). Grauerholz, L. 2001. Teaching Holistically to Achieve Deep Learning. College Teaching: Spring. Vol. 49, No. 2. p.2. College Teaching, 49(2).

Haryanti, D., Nasution, H., \& Sukamto, A. S. (2016). Sistem Pendukung Keputusan Seleksi Penerimaan Mahasiswa Pengganti Beasiswa Penuh Bidikmisi. Jurnal Sistem Dan Teknologi Informasi, 1(1).

Hendrayana, A., Thaid, D., \& Rosnenty, R. (2014). Motivasi belajar, kemandirian belajar dan prestasi belajar mahasiswa beasiswa bidikmisi di upbjj ut bandung. Jurnal Pendidikan Terbuka Dan Jarak Jauh, 15(2), 81-87.

Joanne V. Wood. (1989). Theory and Research Concerning Social Comparisons of Personal Attributes. Psychological Bulletin, 106(2), 231-248.

Keig, L. (2001). The role of faculty in assessing colleagues' teaching. Journal of Higher Education, 72(5), 612-619.

Keinänen, M., Ursin, J., \& Nissinen, K. (2018). Studies in Educational Evaluation How to measure students ' innovation competences in higher education: Evaluation of an assessment tool in authentic learning environments. Studies in Educational Evaluation, 58(May), 30-36. https://doi.org/10.1016/j.stueduc.2018.05.007.

Kilgus, S. P., Bonifay, W. E., Embse, N. P. Von Der, Allen, A. N., \& Eklund, K. (2018). Evidence for the interpretation of Social , Academic , and Emotional Behavior Risk Screener ( SAEBRS ) scores: An argument-based approach to screener validation is. Journal of School Psychology, 68(March), 129-141. https://doi.org/10.1016/j.jsp.2018.03.002.

Lassig, C. (2020). A typology of student creativity: creative personal expression, boundary pushing and task achievement. Thinking Skills and Creativity, 36(April), 100654. https://doi.org/10.1016/j.tsc.2020.100654.

Maas, B., Tscharntke, T., A, T., Saleh, S., \& Edy, N. (2017). Effects of Ecosystem Services Provided by Birds and Bats in Smallholder Cacao Plantations of Central Sulawesi Dampak Jasa Ekosistem yang Diberikan oleh Burung dan Kelelawar di Kebun Kakao Rakyat di Sulawesi Tengah.

Maggin, D. M., Johnson, A. H., Chafouleas, S. M., Ruberto, L. M., \& Berggren, M. (2012). A systematic evidence review of school-based group contingency interventions for students with challenging behavior is. Journal of School Psychology, 50(5), 625-654. https://doi.org/10.1016/j.jsp.2012.06.001.

Meens, E. E. M., Bakx, A. W. E. A., Klimstra, T. A., \& Denissen, J. J. A. (2018). Learning and Individual $\mathrm{Di}$ ff erences The association of identity and motivation with students academic achievement in higher education. Learning and Individual Differences, 64(March), 54-70. https://doi.org/10.1016/j.lindif.2018.04.006.

Meyers, S. (2003). Strategies to prevent and reduce conflict in college classrooms. College Teaching, 51(3), 94.

Miller, W. (2003). The Role of the Teacher in Agricultural Education. The Agricultural Education Magazine., 25(4).

Moleong, L. J. (1991). Metode Penelitian Kualitatif (3rd ed.). Remaja Rosdakarya Offset, Bandung.

Ott, R. L., \& Longnecker, M. (2001). An introduction to Statistical methods and data analisys (5th ed.). Duxbury.

Prasetyaningsih, S. (2015). Penyebab Motivasi Berprestasi Rendah Pada.

Purnastuti, L., \& Izzaty, R. E. (2016). Access and Equity in Higher Education in Indonesia: A 
Review from the Periphery. In Widening Higher Education Participation. Elsevier Ltd. https://doi.org/10.1016/B978-0-08-100213-1.00008-1.

Reddy, L. A., Hua, A., Dudek, C. M., Kettler, R. J., Lekwa, A., Arnold-berkovits, I., \& Crouse, K. (2019). Studies in Educational Evaluation Use of observational measures to predict student achievement is. Studies in Educational Evaluation, 62(August 2018), 197-208. https://doi.org/10.1016/j.stueduc.2019.05.001.

Rifa'i B, M. (2018). Beasiswa bidikmisi dalam perspektif ekonomi Islam.

Saifudin, A. (2017). Analisis manajemen pembiayaan pendidikan dalam meningkatkan kualitas sumbderdaya manusia menurut perspektif ekonomi islam.

Sampurno, Y., \& Efendi, Y. (2014). Karakteristik mahasiswa bidikmisi jurusan Pendidikan Teknik Otomotif (Vol. 5, Issue 20).

Santoso, S. (2012). Aplikasi SPSS pada statistik non Parametrik (1st ed.). Gramedia.

Shaw, D., Barcastro, S., \& Thiessen, D. (2002). A teaching discussion group in your department-it can happen! College Teaching, 50(1), 29.

Stamatoplos, A. (2000). An integrated approach to teaching research in a first-year seminar. College Teaching, 48(1), 33.

Takriyuddin, H., Mukmin, Z., \& Yunus, M. (2016). Pengaruh beasiswa bidikmisi terhadap prestasi belajar mahasiswa program studi pendidikan pancasila dan kewarganegaraan Fakultas Keguruan dan IImu Pendidikan Universitas Syiah Kuala. Jurnal IImiah Mahasiswa Pendidikan Kewarganegaraan Unsyiah, 1(19), 49-60.

Usman, U., \& Daud, M. (2015). Science and Technology Program for Entrepreneurship ( STPE ) of Malikussaleh University in North Aceh. 4(October), 49-57.

Vignery, K., \& Laurier, W. (2020). Achievement in student peer networks: A study of the selection process, peer e ff ects and student centrality. International Journal of $\begin{array}{lll}\text { Educational } & \text { Research, } & \text { 99(March }\end{array}$ https://doi.org/10.1016/j.ijer.2019.101499.

Wahyuningsih, S. (2016). Empowering Academic Writing Skills in Millennial Era. The 2nd National Telecon, 108-114.

Wasahua, T., Koesmaryono, Y., \& Sailah, I. (2018). Evaluation Policy on Assistance Program Bidikmisi Higher Education in Private Kopertis Region XII. Journal of Education and eLearning Research, 5(1), 1-7. https://eric.ed.gov/?id=EJ1167155.

Wibowo, U. B., Sudiyono, S., \& Lestari, S. (2019). The Bidikmisi Scholarship: What Work and What Doesn't Work?. KnE Social Sciences, 154-162. https://doi.org/10.18502/kss.v3i17.4635.

Yin, R. (2000). Studi Kasus; Desain dan Metode. Penerbit PT. Radja Grafindo Persada.

Yusuf. (2018). The Influence of Quality Academic Service on Student Satisfaction ( Empiric Study on Bidikmisi Scholarship Students Regional Office of Universitas Terbuka at Pangkalpinang , Indonesia ). Integrated Journal of Business and Economic, 2(2), 4056. https://dx.doi.org/10.33019/ijbe.v2i2.75.

Zhou, S., Zhou, W., \& Traynor, A. (2020). Parent and teacher homework involvement and their associations with students ' homework disaffection and mathematics achievement. Learning and Individual Differences, 77(February 2019), 101780. https://doi.org/10.1016/j.lindif.2019.101780. 